Darja Kerec

\title{
The Role of Russia and the Soviet Union in the History of Prekmurje
}

In the spring of 1919, Prekmurje was still a part of Hungary, where Communists, who had joined forces with the Social Democrats, assumed power on 21 March 1919 in what was essentially a coup. The people living in Budapest and the countryside were taken aback by the establishment of the Republic of Councils and were not in favour of the dictatorship of the proletariat. Vilmoš Tkalec, a teacher and church choirmaster (cantor), was active in Prekmurje at that time. During the war, he fought on the Russian Front, where he was also held captive in $1917 .{ }^{1}$ After returning home, he worked as a commander of the Hungarian Border Police along the Mura River and as a civil commissioner in Murska Sobota. In late December 1918, around 100 Yugoslav volunteer soldiers, commanded by the Croatian Captain Jure Jurišić, occupied Murska Sobota; they were driven out in the early morning hours on 3 January 1919 by the Hungarian Army. The proletarian rule committed no atrocities, there were no assassinations, attacks on people's property or seizures of plants. ${ }^{2}$

After the coup d'état in Hungary in April 1919, Tkalec adopted the ideas of Hungarian bolshevism and was elected president of the Workers' Soviet. He became a commissioner for the Slovene March, the Slovenian-speaking area of Prekmurje. He was an interesting character. He became involved in smuggling, which is why detectives came all the way from Budapest to Murska Sobota. ${ }^{3}$ Hence, for his own legal and political protection, he soon turned into a counter-revolutionary and even strove to establish an autonomous state or to break away Prekmurje from Hungary. Thus on 29 May 1919 in Murska Sobota, on the balcony of the Dobrai Hotel at 11:30 a.m., he declared the so-called Mura Republic. He was supported by some soldiers who wanted to overthrow

1 Knjižnica MS, Tkalec Vilmoŕ; Slovenska biografija, Tkalec.

2 Viri za Prekmurje, p. 276.

3 Ibid. 
the dictatorship of the proletariat. This republic was founded as a one-man campaign because the people of Prekmurje were not even aware of it. Tkalec even sent a telegram to the leader of Hungarian Communists, Béla Kun, saying that the so-called Slovene March, that is the Slovenian-speaking region which included Prekmurje and part of the Raba Valley, had been transformed into an autonomous republic, and that the nation was not in favour of Communist principles and therefore might turn to Austria for help. ${ }^{4}$ The republic was over in less than a week. Units of the Hungarian Red Guard occupied Murska Sobota on 3 June 1919. On 6 June, all battles ended. On 12 August 1919, the army of the Kingdom of SCS took control of the region of Prekmurje with an international mandate.

The military and political leaders of the Mura Republic retreated across the border to Austria where they were captured. Tkalec soon returned to Prekmurje as the leader of the "White Guard", but was caught and imprisoned in Lendava. ${ }^{5} \mathrm{He}$ miraculously escaped from prison to Hungary where he lived until his death in 1950.

The greatest impact of the Russian Revolution in Prekmurje can be seen in the fact that some of the Bolshevik soldiers engaged in plundering. They looted the manor of the Hungarian Count Avgust Zichy in Beltinci near Murska Sobota and the warehouses of certain traders and started fires in Croatia, for instance in the settlement of Štrigova in the Međimurje region. ${ }^{6}$ The events in Russia also affected the younger generation. On 6 July 1919, the Young Communist Workers' Society was established in Murska Sobota ${ }^{7}$ and a week later the local Social Democratic Party merged with the Communists. ${ }^{8}$

In March 1919, an agency of the Hungarian Republic of Councils led by Tkalec took control of the central local newspaper Novine (Newspaper), which was edited by the Catholic priest Jožef Klekl. Ironically, it was Klekl himself who had published the news of Cadet Vilmoš Tkalec, a wounded prisoner on the Russian Front. ${ }^{9}$ Until 12 August, when Yugoslav troops occupied Prekmurje, the paper was published as Proletarske Novine (Proletarian Newspaper) and Rdeče Novine (Red Newspaper), but was not popular among readers. During World War I, as the editor of the paper, Klekl had a lot of influence on the emotions and attitudes of readers towards anything Russian. His attitude towards Russia was negative. In his articles he portrayed Russians as the "enemies" and Orthodox Christians who had betrayed the Catholic religion.

Jožef Klekl, who died in 1948, remained politically and socially active even in the Kingdom of Yugoslavia. His negative experience with Bolsheviks was reflected in this new state. He was a harsh critic of the liberal ideas penetrating the local cultural

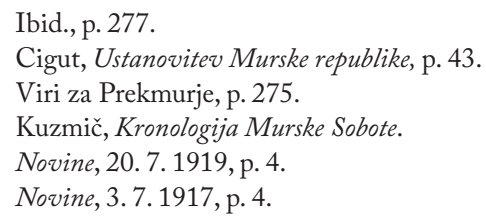


environment from abroad, including the Soviet Union. In his newspaper Marijin list (Mary's Paper) in March 1941, Klekl wrote that the Croatian Katoliški list (Catholic Paper) had expressed its concern over cinemas, which did not teach morality as a public educational institution should. He was troubled by the fact that "Marxist propaganda" was spreading throughout Slovenia and Croatia and that "Soviet films, though clad in the Russian national cloth, have a propagandist nature." A month later, Yugoslavia was at war and Klekl's apprehensions of "Russian propaganda" came true. A special kind of symbolism was also evident in the first film shown in Murska Sobota after the arrival of the Red Army in Prekmurje. On 4 April 1945, a few days after the liberation, the cinema Grajski kino showed a Soviet film with a telling title of "6 Minutes after Victory". The soldiers of the Red Army had brought it with them and it is no wonder that the auditorium was sold out. The local newsletter of the Liberation Front reported that "after so many years of occupation, the showing of this film was a great cultural experience for the viewers." 10

So, on 3 April 1945, Prekmurje or Murska Sobota was liberated by Red Army soldiers, who belonged to the left wing of the Third Ukrainian Front. The arrival of the Russians held material and spiritual consequences for Murska Sobota and for the entire region along the Mura River; the Russians did not set foot on other parts of Slovene territory. The first consequence of the arrival of the Red Army soldiers was the establishment of "Russian authorities": from April to mid-May the Mayor of Murska Sobota was the Red Army Major Fedor Barsukov. In January 1945, the sole Prekmurian army formation, Prekmurska četa [Prekmurian corps], was founded, whose fighters participated in the final operations together with the members of the Red Army. Because of another Hungarian occupation, the reaction to the arrival of the Russian liberators was positive, but this would not remain for long; after 1948 the attitude towards the Soviet Union and Stalin changed as it had elsewhere, both in Slovenia and Yugoslavia. In the first two years after the liberation, one can speak of an almost symptomatic affection towards the Red Army soldiers (with the exception of the clergy, the expropriated industrialists and the inhabitants of Hungarian nationality). This affection is reflected primarily in the news items from two local newspapers: Novi čas and Ljudski glas (Voice of the People), which informed the Slovenes of Prekmurje about events around the world and at home on a daily and weekly basis, respectively. As a rule, one to two pages were dedicated to news items or reports on the advances of the Red Army and the allies across Europe and two more pages to local events (funerals of Red Army soldiers who fell on Prekmurian land, assemblies and celebration in gratitude to the liberators, and voluntary (humanitarian) collection campaigns by the local population for Russian soldiers). As early as 12 August 1945, a victory monument, over 17 metres tall, was unveiled in the

10 Kerec, Od Talije, p. 821.

11 Kerec, Red Army, p. 99. 
centre of Murska Sobota, on Trg zmage; the monument was a result of Russian-Slovene co-operation (the work of the military engineer Arončik and the Kalin brothers, who made the monuments of the partisan and the Red Army soldier). Similarly to the Prešeren Monument in the centre of Ljubljana, the Murska Sobota victory monument, despite post-independence initiatives for its removal, is still a landmark and one of the chief architectural and artistic monuments of Murska Sobota, and, in a broader sense, a unique attraction: this monument is in fact the only one of its kind on Slovene soil. ${ }^{11}$

This was a time of inclusion in post-war life, of many work campaigns (which did not stop over the years) and preparations for elections to the constituent assembly on 11 November 1945. This was also the time for the first analyses of the merits of individuals for liberating Prekmurje and the accusations of collaborating with the occupiers. Inhabitants along the Mura River did not exactly favour the Russian liberators, which is why the euphoria during the unveiling of the monument on Trg zmage was most likely insincere, even though the politics and the renovation of the town and landscape did not give up on Stalin's legacy until 1948. ${ }^{12}$ By 1948, much ink had been used to write about the mutual affection between Stalin and Tito; the spirit of mutual acknowledgment of the merits for liberation was also demonstrated by the fact that Marshal Tito was awarded the Order of Victory. Less than a month after the unveiling of the monument in Murska Sobota, Ambassador Sadčikov awarded Tito with the highest Soviet decoration. ${ }^{13}$

The unveiling of the monument was reported by several newspapers, all of which unanimously welcomed the solemn event and praised the Russian liberators as Slavic brothers and allies: "Last Sunday Prekmurje witnessed a grand manifestation: the unveiling of the Monument of Victory and Eternal Brotherhood. This mighty monument is an artistic work of contemporary sculpture. It stands on a large market in the centre of the town. It was erected by the Slovene people in gratitude to and memory of the fighters of the celebrated Red and Yugoslav Armies." The preserved photographs taken on the day of the unveiling of the monument, at first glance do not show a crowd of people joining in the celebration; in the published news items representatives of the Red Army with the Soviet Ambassador Sadčikov are mentioned above all. ${ }^{14}$

12 Ibid., p. 82.

13 Ibid., p. 84.

14 Ibid. 


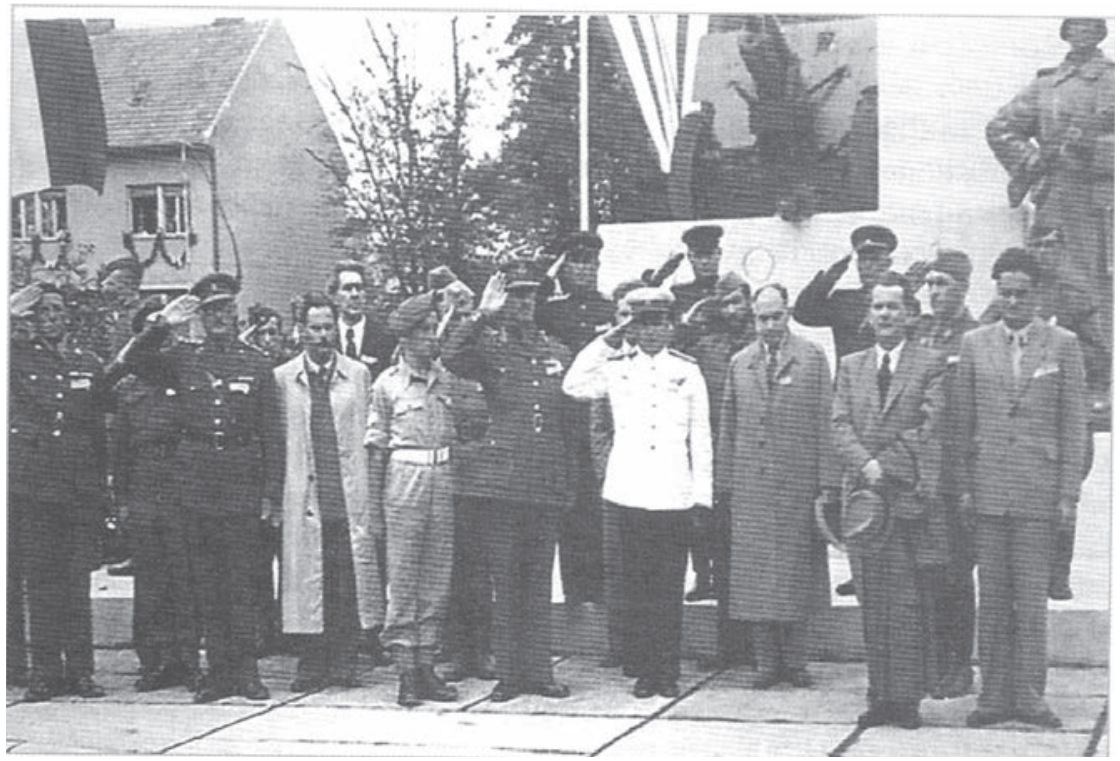

Photo 1: The unveiling of the victory monument on 12 August 1945

(Pokrajinski muzej Murska Sobota. Katalog stalne razstave, p. 321.)

A direct consequence of the Cominform conflict was the iron curtain in the east of Prekmurje. All road connections to Hungary were closed. Until 1948, there were as many as 9 border crossings in Prekmurje along the Hungarian state border. ${ }^{15}$ In the Raba Valley, on the Hungarian side, one consequence was a hysteria of sorts, directed at Tito; preparations for war also included a preventive "cleansing" of the zone bordering with Yugoslavia. Slovenes in Hungary became potential enemies of the Hungarian Communist regime. In Prekmurje, people were worried because of the systematic Hungarization of Slovenes in the Raba Valley. During the population census of January 1949, Slovenes were forced

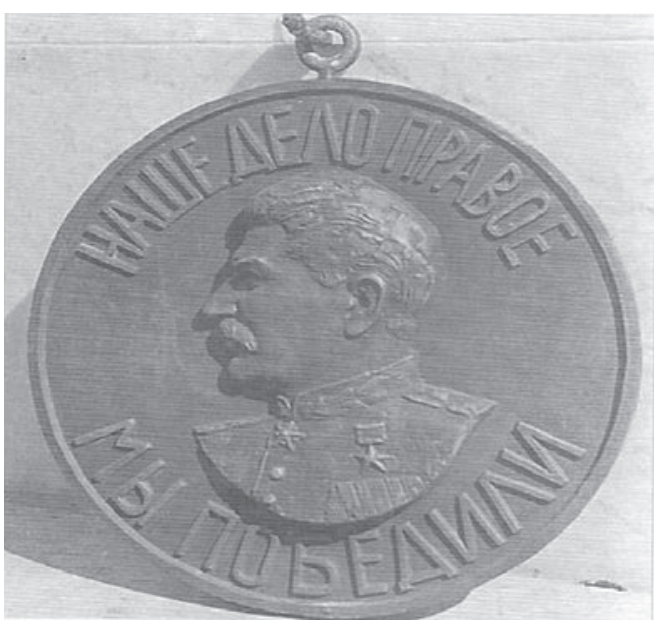

Photo 2: The monument originally included Stalin's image, which was taken down demonstratively during the conflict with the Information Bureau (Pokrajinski muzej Murska Sobota. Katalog stalne razstave, p. 322.) to declare themselves Hungarian. Many 
who resisted were arrested; in prison they were forced to declare themselves against Yugoslavia in exchange for freedom. Hungarian authorities formed a $15 \mathrm{~km}$ border zone along the Yugoslav and Austrian borders; only the people who had a special card were allowed to linger there. The border separating Hungary from Austria and Yugoslavia was sealed. The border zone was protected by state security bodies. This was manifested in the numerous proceedings initiated against people for suspected espionage and smuggling of people; the police exerted control over the population and people were being exiled or deported. Many ended up on the lists of kulaks or deportees, or were punished for not paying the mandatory tribute in field crops because they did not want to join agricultural cooperatives. ${ }^{16}$

The Cominform conflict aggravated the already poor economic situation in the mostly rural region of Prekmurje. It was mandatory to hand over any agricultural surplus. People were required to join agricultural cooperatives. Between 1949 and 1951, the number of court proceedings against farmers increased. At the so-called kulak proceedings, mostly large farmers were convicted of illegal speculation and sabotage, and of opposing the establishment of agricultural cooperatives. ${ }^{17}$ Courts passed stricter sentences than in previous years; these were mainly fines and prison sentences. Those who had kept the crop surplus for themselves or had made a profit were labelled speculators, for instance millers and traders. ${ }^{18}$

Yugoslav authorities devoted special attention to the youth and pointed out the so-called witch-hunt against the Cominformists, warning young people of it at special educational courses for the youth. At a conference in Ljutomer in March 1949, members of the Youth Organisation adopted a resolution in which they condemned Radio Budapest for spreading lies on the air about socialism in Yugoslavia, Tito, the Communist Party and the work campaigns of the Yugoslav youth. ${ }^{19}$ In September, a youth protest rally against the Hungarian government was held in Murska Sobota. ${ }^{20}$

From July 1948 to the end of 1949, the central newspaper in Prekmurje Ljudski glas (Voice of the People) published news about Cominform agitators (called informisti or informkričači in Slovenian). They appeared at the border in Hodoš, where the Hungarian minority lived. However, the local authorities stressed that national minorities had the same rights and obligations in Yugoslavia as the rest of the population, and that they therefore sided with Yugoslav socialism and joined agricultural cooperatives.

Industrial workers also felt the aftermath of the Cominform conflict. In the company Proizvodnja nafte (Oil Production) in Lendava, workers experienced difficulties in the spring of 1949 because some of the countries that had previously supplied machines

16 Munda Hirnök, Represija nad Slovenci, pp. 203-204.

17 Čoh Kladnik, Ozadje sodnih procesov, p. 70.

18 Roudi, Življenje v Prekmurju, p. 89.

19 Ljudski glas, 24. 3. 1949, p. 1.

20 Ljudski glas, 22.9.1949, p. 1. 
for oil production activities stopped supplying them due to the conflict or had sent machines that did not work. ${ }^{21}$ Factories organised competitions for realising the annual plan. In December 1949, Tovarna perila Mura (Mura Clothing Factory) in Murska Sobota organised a six-hour competition with Tovarna perila (Clothing Factory) in Zagreb to boost performance. The Mura factory informed the public that the campaign was its reply to "all of the slander and lies being spread by the Cominform countries". Such work performance competitions were adopted by all the major companies, especially in the construction industry. ${ }^{22}$

\section{Sources and literature}

\section{Sources}

Ljudski glas. Glasilo osvobodilne fronte ob murskib krajev, 24. 3.1949, p. 1.

Ljudski glas. Glasilo osvobodilne fronte ob murskih krajev, 31.3.1949, p. 3.

Ljudski glas. Glasilo osvobodilne fronte ob murskib krajev, 22. 9.1949, p. 1.

Ljudski glas. Glasilo osvobodilne fronte ob murskib krajev, 20.10.1949, p. 2.

Ljudski glas. Glasilo osvobodilne fronte ob murskib krajev, 1.12.1949, p. 2.

Viri za zgodovino Prekmurja: zbirka dokumentov. Források a Muravidék történetéhez: szöveggyújtemény. Szombathely-Zalaegerszeg: Vas Megyei Levéltár-Zala Megyei Levéltár, 2. zvezek: 1850-1921, 2008.

\section{Literature}

Cigut, Natalija, Ustanovitev Murske republike v luči sočasnega časopisja. Maribor: Filozofska fakulteta, 2017.

Čoh Kladnik, Mateja, Ozadje sodnih procesov proti kmetom v severovzhodni Sloveniji po sporu $\mathrm{z}$ informbirojem (1948-1951). Časopis za zgodovino in narodopisje letnik 87/52, zv. 3, 2016, pp. 61-84.

Kerec, Darja, Murska Sobota and Red army's arrival: its influence on architecture, culture and everyday life. Studia Historica Slovenica: časopis za humanistične in družboslovne študije letn. 12, št. 1, 2012, pp. 79-99.

Kerec, Darja, Od Talije do gospodične predsednice (Gledališka in kino ponudba v Murski Soboti med obema vojnama). Nečakov zbornik: procesi, teme in dogodki iz 19. in 20. stoletja. Znanstvena monografija. Ljubljana: Znanstvena založba Filozofske fakultete, 2018, pp. 801-824. Klekl, Jožef, Novine letn. 6, št. 53, 1919, p. 4.

Knjižnica Murska Sobota, Tkalec Vilmoš (http://www.pomurci.si/osebe/tkaleczvilmo\%C5\% A1/629/).

21 Ljudski glas, 31.3.1949, p. 3 and 20.10.1949, p. 2.

22 Ljudski glas, 1.12.1949, p. 2. 
Kuzmič, Franc, Kronologija Murske Sobote 1255.-2008. Murska Sobota (http://www.pomurskimuzej.si/izobrazevanje/gradiva-pomurja/murska-sobota/kronologija).

Munda Hirnök, Katalin, Represija nad Slovenci v Porabju v času Rákosijevega režima (19481956). Prispevki za novejšo zgodovino LIII - 1/2013, pp. 201-212.

Olas, Ludvika and Božidar Kert, Vpliv državnih meja na družbeno geografski razvoj Prekmurja. Prispevek na konferenci. Dela - Oddelek za geografijo Filozofske fakultete v Ljubljani, št. 10, 1993, pp. 135-143.

Roudi, Bernarda, Življenje v Prekmurju, ko so v obdobju 1945-1953 uvajali ukrepe socialistične oblasti. Zgodovina v šoli št. 3-4, letn. XX, 2011, pp. 79-92.

Slovenska biografija, Tkalec, Viljem (https://www.slovenska-biografija.si/oseba/sbi702024/).

Šteiner, Martin, Prekmurje pod rdečo zvezdo. Murska Sobota: Katalog stalne razstave. Pokrajinski muzej, 1997, pp. 321-326.

\section{Summary}

\section{Darja Kerec}

\section{The Role of Russia and the Soviet Union in the History of Prekmurje}

Despite the end of World War I, Prekmurje remained a part of Hungary until mid-August 1919. The border between the Republic of Hungary and the Kingdom of Serbs, Croatians and Slovenians was finally demarcated at Trianon on 4 June 1920. The inhabitants of Prekmurje, Slovenians and Hungarians alike, had already become accustomed to uncertain political circumstances during the four years of war. They had been informed of the events of the February (Bourgeois) and October Revolution of 1917, and they awaited the outcome of the war in fear. Prekmurje was the only part of Slovene territory, at the time still a part of Hungary, to be affected by the revolution. In the media in period between the two World Wars (1918/19 to 1941), representatives of the Roman Catholic Church and the local authorities would often express their fear of Bolshevism, social democracy, Marxism and the influence of the Soviet Union, which was only marginal at the time. All of that changed during World War II; as early as 3 April 1945, Russian soldiers (the Red Army, made up of the left wing of the 3rd Ukrainian Front) marched into Prekmurje (Murska Sobota) and liberated it. As the grand victor, the Soviet Union immortalised its military and administrative presence by building and solemnly unveiling a victory monument in the centre of Murska Sobota on 12 August 1945. This monument glorifying a Red Army soldier and a partisan would most likely not have been erected in 1948 (the conflict with the Cominform); however, the government did adopt the Act on the Protection of Cultural Monuments and Natural Features that very year. This monument 17 metres tall was designed by the Russian architect Jurij Arončik, while the two bronze sculptures are the work of the Kalin brothers (the partisan was sculpted by Zdenko, and the Red Army soldier by Boris Kalin). A Russian T-34 tank is also a part of the monument. This was followed by a decade of post-war reconstruction and accelerated industrialisation, and the Russian influences subsided for a while, as they did elsewhere throughout the then Yugoslavia. A demonstrative act in the conflict between Tito and Stalin was the removal of Stalin's image from the top of this monument. In the mid-1950s, events in Hungary once again put the attitude of Slovenians (Yugoslavs) towards the Soviet Union to the test; especially in 
Prekmurje and along the border with Hungary, which was sealed tight. In late 1956, Hungarian refugees retreated to the Yugoslav side (according to the available data, close to 2,300 of them sought shelter in Slovenia). Later on, the Yugoslav authorities attempted to resolve their status with a special asylum policy. Until the end of the Cold War, the democratisation of Hungary, and Slovenia's attainment of independence, the border between Yugoslavia and Hungary was strictly guarded on the Prekmurje side; many still remember that an ordinary crossing of the border was quite an adventure for Yugoslav tourists and consumers, because on the Hungarian side not only Hungarian customs officers awaited them, but Soviet soldiers as well. 